УДК 378.016:811(477)

DOI:

Любов Гарапко, аспірантка кафедри англійської філологї̈ та методики викладання іноземних мов Мукачівського державного університету

\title{
КОНЦЕПТУАЛЬНІ ЗАСАДИ ЗАРУБІЖНОЇ ІНШОМОВНОЇ ОСВІТИ В НАУКОВОМУ ДИСКУРСІ УКРАЇНСЬКОЇ КОМПАРАТИВІСТИКИ
}

У статті здійснено аналіз відображення у науковому дискурсі української педагогічної компаративістики концептуальних засад (методологічних підходів, мети, принципів тошо) іншомовної освіти в зарубіжних країнах. Для репрезентативного вивчення иієї проблеми методом головного масиву охоплено близько 70 дисертацій і 20 монографій, а вибірковим методом - майже 100 статей. Принципи іншомовної освіти визначено як вихідні базові положення, щзо проєктують ї̈ функціонування у зарубіжжі. Визначено три домінуючі підходи украйнських учених до тлумачення принципів іншомовної освіти. Першийформалістичний, коли вони ототожнюються із загальними принципами розвитку системи освіти Украйни або досліджуваної країни. Другий підхід полягає в ототожненні принципів іншомовної освіти з приниипами навчання іноземних мов; третій - передбачає їхне визначення на основі основоположних міжнародних $i$ європейських нормативних документів та національних державних нормативно-правових.

Ключові слова: іншомовна освіта; педагогічна компаративістика; науковий дискурс; мета іншомовної освіти; принципи іншомовної освіти.

Табл. 2. Літ. 13.

Lyubov Harapko, Postgraduate Student of the English Philology and Teaching Methods of Foreign Languages Department of Mukachevo State University

\section{CONCEPTUAL FUNDAMENTALS OF FOREIGN LANGUAGE EDUCATION IN THE SCIENTIFIC DISCOURSE OF UKRAINIAN COMPARATIVE STUDIES}

The article analyzes the reflection in the scientific discourse of Ukrainian pedagogical comparative studies of the conceptual block of foreign language education in foreign countries. It consists of methodological approaches, goals and principles. For a representative study of this problem, the main array method covers about 70 dissertations and two dozen monographs, and the selective method-about a hundred articles.

It was found that when studying foreign language education abroad, scientists relied on the methodological approaches of the three main groups: general scientific (systemic, synergetic, phenomenological, axiological, etc.), general didactic (communicative, competence, activity-oriented, personality-oriented, etc.); special (cross-linguistic, post-communicative, etc.). The target component of foreign language education is defined as a set of its general and special goals arising from international regulations and national legislation, educational paradigms, pedagogical theories. According to certain features, the approaches of scientists to the definition and formulation of the purpose of foreign language education in foreign countries are systematized and characterized.

The third component of the conceptual block, which deals with the principles of foreign language education, is defined as the starting point of the basic provisions that project its functioning abroad. There have been identified three dominant approaches of Ukrainian scientists to the definition and interpretation of the principles of foreign language education. The first is formalistic, when they are identified with the general principles of development of the education system of Ukraine or the country under study. The second approach is to identify the principles of foreign language with the principles of teaching foreign languages, which is not entirely justified, because they are didactic in nature and do not reflect the full phenomenon of foreign language education, which has a cultural component. The third most optimal approach involves determining the principles of foreign language education on the basis of fundamental international and European regulations and national state regulations on its development. It is described in detail in some examples.

Keywords: foreign language education; pedagogical comparative studies; scientific discourse; purpose of foreign language education; principles of foreign language education.

П

остановка проблеми. Сучасні процеси глобалізації та інтеграції України у світовий освітній простір актуалізували потребу вивчення зарубіжного досвіду розвитку освітніх систем для його використання у реформуванні національної системи освіти та вдосконаленні змісту освітнього процесу. Особливої значущості в цій сфері набула проблема іншомовної освіти, адже володіння іноземними мовами є важливою передумовою адаптації в нових етнокультурних середовищах, розширення міжкультурних контактів, успішного працевлаштуванні за кордоном тощо. 


\section{КОНЦЕПТУАЛЬНІ ЗАСАДИЗАРУБІЖНОЇ ІНШОМОВНОЇОСВІТИ}

\section{В НАУКОВОМУ ДИСКУРСІ УКРАЇНСЬКОӤ КОМПАРАТИВІСТИКИ}

Зважаючи на синтез наукового досвіду українських компаративістів (В. Гаманюк, О. Максименко, С. Каричковська, О. Першукова, М. Тадеєва та ін.), визначено інтегровану модель розвитку іншомовної освіти в зарубіжних країнах. Вона передбачає аналіз наукового дискурсу цієї проблеми на основі розгляду чотирьох основних ієрархічно взаємозумовлених структурних блоків: 1) концептуальний - відображає методологічні підходи, мету, принципи іншомовної освіти; 2) змістовий - розкривається в освітніх стандартах, програмах, інших елементах, що становлять курикулум навчання іноземних мов $\mathrm{i}$ культури їхніх носіїв; 3 ) методичний (діяльнісний) - охоплює сукупність методів, форм, технологій і засобів, що забезпечують організацію цього навчального процесу; 4) результативний - фіксує його результати у вигляді сформованих знань, умінь, компетентностей та систем і методів їхнього визначення, контролю, оцінювання тощо.

Складність осмислення наукового дискурсу означеної моделі зумовлюється особливостями iii реалізацією в окремих країнах і регіонах, на різних рівнях освіти, наповненістю різними елементами, іншими чинниками. Для системності та цілісності їі аналізу апробовано дворівневу систему координат, яка передбачає: “подіагоналі” - поступальний розгляд означених вище блоків; “по-діагоналі" - з'ясування їхніх характеристик на різних рівнях освіти (початкова, середня, вища, вища професійна тощо) та в національних вимірах окремих країн.

Запропонована модель вивчення наукового доробку про розвиток іншомовної освіти відповідає двом концептуалізованим у педагогічній науці підходам дослідження освітнього процесу. Перший стосується його розгляду з процесуальної точки зору як сукупності п'яти-шести основних компонентів: 1) цільового як сукупності пов'язаних загальних, індивідуальних, інших цілей освіти; 2) змістового - виражається у змісті освітньої діяльності, спрямованої на досягнення висунутих цілей;

3) організаційно-діяльнісного - визначається рівнями управління професійною діяльністю педагогами та взаємодії з вихованцями;

4) комунікативного - визначає характер і стиль взаємин між ними та в педагогічному колективі; 5) контрольно-оцінного - включає контроль і оцінку результату освітньої діяльності; 6) аналітичний передбачає узагальнення результатів освітньої діяльності через їхнє зіставлення з висуненими цілями.

Другий концептуальний підхід представлений у студіях про розвиток іншомовної та білінгвальної освіти в зарубіжжі, де вона розглядається як система мовленнєвої підготовки на різних рівнях освіти певних категорій учнівської молоді, майбутніх фахівців, дорослих тощо. У них у різних форматах автори акцентують на таких компонентах, як мета освіти (освітнього процесу), зміст, методи і форми організації, навчальнометодичне забезпечення, визначення результатів і наслідків тощо.

3 огляду на означені методологічні підходи, перший концептуальний блок нашої структурної моделі є основоположним і визначальним для трьох наступних. Тому предметний аналіз його трактування в дослідженнях 3 педагогічної компаративістики набуває особливої актуальності i значущості для науково-теоретичного i практичного вдосконалення процесу навчання іноземних мов в Україні.

Аналіз актуальних досліджень і публікацій. Оскільки наше дослідження присвячене науковому дискурсу про розвиток іншомовної освіти в зарубіжжі, окреслимо важливі для його аналізу риси й особливості. По-перше, дослідження з цієї проблеми мають міждисциплінарний характер. Він виявляється в підготовці їх на перетині педагогіки, лінгвістики та деяких інших гуманітарних наук. По-друге, у вивченні означеної проблематики простежуємо термінологічні суперечності, що виявляються у різних тлумаченнях термінів “білінгвальна”, “полілінгвальна”, “іншомовна" освіта та ін. Це відповідним чином позначається на розумінні сутності та характеру досліджуваних процесів і явищ. По-третє, за умов зростаючого наукового плюралізму розширюється тематика студій та урізноманітнюється трактування певних освітніх феноменів, що відповідають сутності окремих національних освітніх систем. Усе це зумовлює потребу здійснення предметного аналізу відображення концептуальних підходів, мети, принципів іншомовної освіти означеного корпусу студій як важливої передумови створення іiі цілісної наукової рецепції.

Мета статті - здійснення синтезованого аналізу нагромадженого у 90-х рр. XX - на початку XXI ст. комплексу досліджень про розвиток іншомовної освіти в зарубіжних країнах на предмет відображення у них ії концептуального блоку, що складається 3 методологічних засад, мети і принципів. Це $\epsilon$ важливою передумовою для створення цілісної наукової рецепції означеної проблеми.

Виклад основного матеріалу. Незважаючи на процеси децентралізації освіти та розширення диференційованості педагогічної теорії, ученікомпаративісти досить одностайні в 


\section{КОНЦЕПТУАЛЬНІ ЗАСАДИЗАРУБТЖНОЇ ІНШОМОВНОӦОСВІТИ}

В НАУКОВОМУ ДИСКУРСІ УКРАЇНСЬКОӤ КОМПАРАТИВІСТИКИ

структуризації розвитку іншомовної освіти в країнах закордоння. Це виявляється у відображенні їі концептуального блоку, що складається $з$ методологічних засад, мети і принципів. Проаналізуємо основні наукові підходи й характеристики цих компонентів у сучасному науково-педагогічному дискурсі України.

Для предметного репрезентативного вивчення цієї проблеми методом головного масиву було охоплено близько 70 дисертацій і 20 монографій, а вибірковим методом - близько 100 статей. 3 них випливає, що в процесі вивчення іншомовної і багатомовної освіти в зарубіжжі науковці вибірково або синтезовано спиралися на методологічні підходи, які можна поділити на три основні групи. Першу становлять загальнонаукові (системний, синергетичний, культурологічний, феноменологічний, аксіологічний та ін.), другу загальнодидактичні (комунікативний, компетентнісний, когнітивний, діяльнісно-орієнтований, особистісно орієнтований та ін.) підходи. Їхні сутнісні характеристики, розроблені вченими різних галузей знань, автори майстерно інтерпретують у ракурсі своїх студій. Це, до прикладу, дисертації В. Корнієнко (2012) про розвиток професійної підготовки бакалаврів гуманітарних наук 3 прикладної лінгвістики в університетах США [5] та О. Першукової (2016) про тенденції розвитку багатомовної освітишколярів українах Західної Свропи в другій половині XX - на початку XXI ст. [9].

Більш диференційованою виглядає третя група спеціальних підходів, що окреслюють методологічні засади розвитку теорії і практики іншомовної освіти. Науковці визначають і трактують їх, зважаючи на аналіз освітніх лінгвосистем досліджуваних країн і регіонів. Зокрема, у студіях, що стосуються європейського регіону, найчастіше вирізнялися такі методологічні підходи організації навчання іноземних мов, як крос-лінгвістичний, пост-комунікативний та ін. Вони стосуються методики і технології практичної організації іншомовної освіти, тож переважно розглядаються в контексті навчання іноземних мов (див, напр.: О. Максименко (2013) [6]; О. Першукова [9, 18-20] та ін.).

Другий складник концептуального блоку, що стосується цільового компонента іншомовної освіти, визначаємо як сукупність іiі загальних і особливих цілей, що випливають 3 міжнародних нормативно-правових та національних законодавчих актів, освітніх парадигм, педагогічних теорій тощо. Він окреслює результат, якого необхідно досягнути в процесі реалізації основної мети іншомовної освіти. Як випливає із систематизованих у таблиці 1 прикладів типових і виразних формулювань мети, вона, згідно 3 канонами педагогічної наук, визначалася авторами на основі предмета дослідження та окреслювала стрижневу лінію, напрям дії об'єктивно i суб'єктивно детермінованої та цілеспрямовано організованої діяльності.

Результати аналізу показали, що, по-перше, науковці часто формально підходять (а подекуди взагалі уникають) визначення мети розвитку іншомовної та білінгвальної освіти в зарубіжних країнах. По-друге, у процесі формулювання цього базового компонента дослідження переважно не враховується та важлива обставина, що мета, попри свою сталість, модифікувалася і змінювалася на різних етапах розвитку освітнього процесу. По-третє, мета відображає лише загальний стратегічний напрям освітньої діяльності, тож її важливі компоненти й аспекти конкретизуються у відповідних завданнях, які здебільшого не окреслювалися авторами.

Відзначаємо позитивний досвід визначення мети і цілей іншомовної освіти в наукових дослідженнях. У докторській дисертації I. Білецької здійснено ретроспективний аналіз цілей навчання іноземних мов на основі курикулумів різних років, які практикувалися в середніх освітніх закладах США та засвідчили зміну акцентів з технічного рівня володіння мовою на практичний. На цій основі була визначена “головна мета” іншомовної освіти (див. табл. 1), досягнення якої передбачало розв'язання низки завдань щодо формування в учнів правильної вимови звуків, слів, речень; оволодіння лексичним матеріалом; набуття знань і вмінь з граматики, читання, усного та діалогічного спілкування; засвоєння відомостей про країну, мова якої вивчається, та ін. Зважаючи на це, обгрунтовується стратегія реалізації мети іншомовної освіти, що передбачає соціокультурний розвиток учнів засобами іншої мови для їхньої підготовки до міжкультурної комунікації у різних сферах життєдіяльності [2, 20-21].

У дисертації Ю. Павлович показана трансформація цілей навчання іноземних мов у початковій школі держав Вишеградської четвірки: до 90-х рр. ХХ ст. вони взагалі не вивчалися на цьому рівні освіти, потім їх почали визначати в руслі політики мультилінгвізму, відтак формулювання цілей почало розширюватися в межах компетентнісного підходу та кристалізуватися у напрямі формування полікультурної багатомовної особистості, здатної навчатися впродовж життя згідно $з$ тенденціями мобільності і працевлаштування тощо [7]. Такий підхід до визначення цілей іншомовної освіти $\epsilon$ 
Приклади визначення мети в дослідженнях про розвиток іншомовної освіти в зарубіжних країнах

Автор та визначена на основі предмету дослідження його мета

О. Першукова: мета розвитку багатомовної освіти школярів у країнах Західної Свропи: розиирення ї̈ репертуару мовами, щуо стали засобами міжнародного спілкування і тими, якими послуговуються рідше; формування у них розуміння соціокультурної цінності лінгвістичного розмаїття; розвиток міжкультурної компетентності [9];

О. Максименко: мета професійно-орієнтованого навчання іноземних мов у країнах Євросоюзу: формування в особи, яка вивчає іноземну мову, комплексу компетентностей (іншомовної, комунікативної з акиентом на професійну та ін.) для забезпечення активної життєдіяльності в полікультурному суспільстві [6];

О. Корніснко: мета професійної підготовки бакалаврів гуманітарних наук з прикладної лінгвістики в університетах США: допомога студентам в оволодінні інтегрованими знаннями, уміннями і навичками у галузі лінгвістики та суміжних наук [5];

І. Білецька: головна мета іншомовної освіти у середніх освітніх закладах США: формування у школярів здатності використовувати іноземної мови як інструменту в діалозі культур у межах своїх краӥн $i$ циивілізацій сучасного світу [2];

Л. Смірнова: мета формування соціокультурної компетентності в структурі підготовки учителів іноземної мови Польщі: професійна підготовка у контексті європейського виміру вищої освіти $і$ діалогу культур та формування культурної свідомості $і$ уміння протистояти культурній дискримінацї й маніпулюванню в будь-яких проявах [11];

В. Смелянська: пріоритетна метою розвитку раннього навчання іноземних мов у початкових школах США є навчання спілкування іниими мовами, окрім англійської, бо саме через комунікацію можна досягти інших освітніх иілей; практичною метою є оволодіння вміннями аудіювання $і$ говоріння, достатніми для здійснення мовленнєвого контакту зі співрозмовником, отримання $i$ передачі елементарної інформачії [10];

В. Базова: мета підготовки викладачів іноземних мов в університетах Німеччини - розвиток іншомовної комунікативної компетениії [1];

I. Пасинкова: мета підготовки бакалаврів гуманітарних наук з іноземної мови в університетах США: забезпечення галузей професійної діяльності фахівцями, які вільно володіють ІМ та здатні розв'язувати професійні завдання в умовах внутрішньої $і$ міжнародної конкуренції завдяки фундаментальної та спеціальної підготовки, отриманої в процесі неперервної ступеневої освіти [8];

Ю. Талалай: мета мовної політики в країнах Центральної Свропи: збільшення кількості іноземних мов, щ̧о вивчаються, розробка рівнів володіння мовами, організація заходів, спрямованих на удосконалення мовної підготовки, модернізація підготовки вчителів, захист культурного і мовного розмаїття [13].

оптимальним і сприйнятливим, адже він ураховує комплекс внутрішніх і зовнішніх (мультикультурність, євроінтеграція та ін.) чинників розвитку та викликів, що стоять перед кожною цивілізованою країною.

Третій складник концептуального блоку стосується принципів іншомовної освіти як вихідних базових положень, що проєктують іiі функціонування у зарубіжжі. Виявлено три домінуючі підходи українських учених до їхнього визначення і трактування. Перший-формалістичний, коли вони ототожнюються із загальними принципами розвитку системи освіти України або досліджуваної країни. Другий підхід полягає в ототожненні принципів іншомовної та білінгвальної освіти з принципами навчання іноземних мов, що не зовсім виправдано, адже останні мають дидактичний характер і не відображають усієї повноти феномену іншомовної освіти 3 іiі культурологічним компонентом.
Третій (найбільш оптимальний і поширений) підхід передбачає визначення принципів іншомовної освіти на основі основоположних міжнародних і європейських нормативних документів та національних державних нормативно-правових актів про iї розвиток. У такому ключі вони розглядаються науковцями: як загальні, властиві усій системі іншомовної освіти досліджуваної країни; у розрізі окремих груп принципів, що стосуються розвитку початкової, середньої, вищої школи, професійної підготовки вчителів, перекладачів; у проєкції дослідження конкретних проблем тощо. Типові приклади визначення українськими компаративістами принципів іншомовної освіти в зарубіжжі представлено в табл. 2.

Цікавим і продуктивним уважаємо досвід, коли дослідники на основі аналізу нормативних і науково-методичного матеріалів пропонують свої 


\title{
Приклади визначення українськими науковцями принципів іншомовної освіти в
}

Таблиця 2. зарубіжних країнах

\begin{abstract}
Автор, принципи іншомовної освіти відповідно до мети і предмету дослідження
О. Першукова: принципи багатомовної освіти школярів у країнах Західної Європи: дидактичний, когнітивний, комунікативний, міжкультурний [9];
\end{abstract}

М. Тадесва: принципи політики розвитку іншомовної освіти в країнах-членах РЄ: використання ефективних форм $i$ засобів навчання регіональних мов на всіх освітніх рівнях; надання місчевим мешканиям права оволодіння ними за власним бажанням; сприяння розвитку наукових досліджень про регіональні мови і мови меншин в університетах $і$ коледжах; розвиток різних форм міжначіональних обмінів з проблем розвитку регіональних мов [12];

О. Максименко: принципи професійно-орієнтованого навчання іноземних мов у країнах Євросоюзу: аналізу потреб; уточнення цілей; цілісності навчання; якості навчання [6];

С. Каричковська: принципи підготовки майбутніх вчителів англійської мови в університетах Польщі і України: диференціачії цілей та завдань професійно- орієнтованого навчання; взаємозв'язку $i$ взаємозумовленості розвитку комунікативних умінь та професійно-орієнтованих методичних умінь; градації труднощів вивчення IM; опори на майбутню практичну професійну діяльність [3];

Л. Смірнова: принципи формування соціокультурної компетентності польського вчителя іноземної мови: мобільності; європейського контексту; культурологічний; професійної значимості [4];

М. Кокор: принципи підготовки майбутніх викладачів іноземної мови за професійним спрямуванням в університетах США: усвідомленого навчання; активності та самостійності; зв'язку навчання $з$ практичною діяльністю; студентоцентризму; систематичності і послідовності; безперервної освіти [11];

І. Білецька: принципи іншомовної освіти в середніх навчальних закладах США: активного вжсияння автентичної мови під час вивчення іноземної мови; вивчення мови для ї̈ використанні, а не набуття знань про неї; системності і диференційованості етапів оволодіння іноземною мовою; вивчення іноземною мовою через наближення до норм ї̈ носіїв; вивчення мови через ї̈ сприйняття $і$ відтворення; застосування мови через розуміння культурного контексту комунікачії; індивідуального стилю вивчення іноземної мови, що враховується в стратегіях учителя; формування уміння застосовувати мову через виконання учнями автентичних, цілеспрямованих завдань [2].

трактування принципів іншомовної освіти зарубіжних країн. Ідеться, до прикладу, про підхід О. Максименко, яка на основі аналізу теорії і практики іншомовної освіти подає власну інтерпретацію принципів професійно-орієнтованого навчання іноземних мов, викладених у Загальноєвропейських рекомендаціях 3 мовної освіти. Отже, зафіксовані в табл. 2 принципи професійно-орієнтованого навчання іноземної мови передбачають структурування його загального та професійного компонентів для врахування мовних потреб особистості в підготовці до життя і професійної діяльності; визначення рівнів опанування мови згідно з видами мовленнєвої діяльності; забезпечення добору матеріалів курсу і методів навчання, адекватних меті та завданням; використання автентичних матеріалів та інформаційно-комунікативних технологій тощо [6].

Висновки і перспективи подальших досліджень. Українська педагогічна компаративістика нагромадила значний досвід визначення та інтерпретації концептуального компонента розвитку іншомовної освіти в зарубіжних країнах. Предметний аналіз наукового дискурсу з цієї проблематики виявив, що їі мета, принципи, інші параметри зазвичай і загалом закономірно розкриваються на основі чинних загальноєвропейських і національних нормативних документів. Однак це не знімає потреби їхньої авторської інтерпретації й оцінки. Поряд із цією прогалиною, також вказуємо на потребу, особливо в комплексних (дисертаційних, монографічних тощо) працях, предметно окреслювати методологічні підходи та мету й принципи іншомовної освіти в досліджуваній країни. Утім, ці компоненти часто випадають з поля зору українських науковців. Перспективи подальших досліджень убачаємо в дослідженні наукових рефлексій, що розкривають зміст розвитку іншомовної освіти в зарубіжних країнах. Певне підгрунтя для розв'язання цього завдання створюють викладені в цій статті матеріали.

\section{ЛІТЕРАТУРА}

1. Базова В. І. Підготовка викладачів іноземних мов в університетах Німеччини: автореф. дис. ... канд. пед. наук: 13.00 .04 . Київ, 2012.20 с.

2. Білецька І. О. Полікультурні засади іншомовної освіти в середніх навчальних закладах США: автореф. дис. ... док. пед. наук: 13.00.01. Умань, 2014. 44 с.

3. Каричковська С. П. Підготовка майбутніх вчителів 


\section{КОНЦЕПТУАЛЬНІ ЗАСАДИ ЗАРУБІЖНОЇ ІНШОМОВНОЇ ОСВІТИ}

В НАУКОВОМУ ДИСКУРСІ УКРАЇНСЬКОӤ КОМПАРАТИВІСТИКИ

англійської мови в університетах України і Польщі (порівняльний аналіз): дис. ... канд. пед. наук: 13.00.04. Київ, 2011.214 с.

4. Кокор М. М. Підготовка майбутніх викладачів іноземної мови за професійним спрямуванням в університетах США: автореф. дис. ... канд. пед. наук: 13.00.04. Тернопіль, 2014. 20 с

5. Корнієнко В. В. Професійна підготовка бакалаврів гуманітарних наук 3 прикладної лінгвістики в університетах США: автореф. дис. ... канд. пед. наук: 13.00.04. Хмельницький, 2012. 20 с.

6. Максименко О. Л. Організаційно-педагогічні засади професійно-орієнтованого навчання іноземних мов у країнах Європейського Союзу: дис. ... канд. пед. наук: 13.00.01. Київ, 2013.305 с.

7. Павлович Ю. П. Розвиток змісту ранньої іншомовної освіти в країнах Вишеградської четвірки (90ті роки XX - перше десятиріччя XXI століття): автореф. дис. ... канд. пед. наук: 13.00.01. Київ, 2017. 20 с.

8. Пасинкова I. В. Система підготовки бакалаврів гуманітарних наук з іноземної мови в університетах США: автореф. дис. ... канд. пед. наук : 13.00.04. Київ, $2005.21 \mathrm{c}$.

9. Першукова О. О. Тенденції розвитку багатомовної освіти школярів у країнах Західної Європи (друга половина XX — початок XXI ст.): автореф. дис. ... док. пед. наук; 13.00.01. Київ, 2016. 44 с.

10. Смелянська В. В. Тенденції розвитку раннього навчання іноземних мов у початкових школах США: дис. ... канд. пед. наук: 13.00.01. Ніжин, 2011.262 с.

11. Смірнова Л. Л. Соціокультурна компетентність у структурі підготовки учителів іноземної мови Польщі: дис. ... канд. пед. наук: 13.00.01. Кіровоград, 2010.293 с.

12. Тадеєва М. І. Сучасні тенденції розвитку шкільної іншомовної освіти в країнах-членах Ради Свропи (порівняльний аналіз): дис. ... док. пед. наук: 13.00.01. Луганськ, 2011.525 с

13. Талалай Ю. О. Модернізація навчання іноземних мов у старших школах країн Центральної Європи в умовах мультилінгвізму: дис. ... канд. пед. наук: 13.00.01. Дрогобич, 2017.236 c.

\section{REFERENCES}

1. Bazova, V. I. (2012). Pidhotovka vykladachiv inozemnykh mov v universytetakh Nimechchyny [Training of foreign language teachers in German universities]. Extended abstract of Candidate's thesis. Kyiv, 20 p. [in Ukrainian].

2. Biletska, I. O. (2014). Polikulturni zasady inshomovnoi osvity v serednikh navchalnykh zakladakh SShA [Multicultural Principles of Foreign Language Education in US Secondary Schools]. Extended abstract of Doctor's thesis. Uman, 44 p. [in Ukrainian].

3. Karychkovska, S. P. (2011). Pidhotovka maibutnikh vchyteliv anhliiskoi movy $\mathrm{v}$ universytetakh Ukrainy i Polshchi (porivnialnyi analiz) [Training of future English teachers in universities of Ukraine and Poland (comparative analysis). Candidate's thesis. Kyiv, 214 p. [in Ukrainian].

4. Kokor, M. M. (2014). Pidhotovka maibutnikh vykladachiv inozemnoi movy za profesiinym spriamuvanniam $\mathrm{v}$ universytetakh SShA [Training of future foreign language teachers in a professional field at US universities]. Extended abstract of Candidate's thesis. Ternopil, 20 p. [in Ukrainian].

5. Korniienko, V. V. (2012). Profesiina pidhotovka bakalavriv humanitarnykh nauk z prykladnoi linhvistyky $\mathrm{v}$ universytetakh SShA [Professional training of bachelors of humanities in applied linguistics at US universities]. Extended abstract of Candidate's thesis. Khmelnytskyi, 20 p. [in Ukrainian].

6. Maksymenko, O. L. (2013). Orhanizatsiinopedahohichni zasady profesiino-oriientovanoho navchannia inozemnykh mov u krainakh Yevropeiskoho Soiuzu [Organizational and pedagogical principles of professionally oriented teaching of foreign languages in the countries of the European. Candidate's thesis. Kyiv, 305 p. [in Ukrainian].

7. Pavlovych, Yu. P. (2017). Rozvytok zmistu rannoi inshomovnoi osvity v krainakh Vyshehradskoi chetvirky (90-ti roky XX - pershe desiatyrichchia XXI stolittia) [Development of the content of early foreign language education in the Visegrad Four countries (90s of the XXfirst decade of the XXI century)]. Extended abstract of Candidate's thesis. Kyiv, 20 p. [in Ukrainian].

8. Pasynkova, I. V. (2005). Systema pidhotovky bakalavriv humanitarnykh nauk $\mathrm{z}$ inozemnoi movy $\mathrm{v}$ universytetakh SShA [The system of training bachelors of humanities in a foreign language at US universities]. Extended abstract of Candidate's thesis. Kyiv, 21 p. [in Ukrainian].

9. Pershukova, O. O. (2016). Tendentsii rozvytku bahatomovnoi osvity shkoliariv u krainakh Zakhidnoi Yevropy (druha polovyna XX - pochatok XXI st.). [Trends in the development of multilingual education of schoolchildren in Western Europe (second half of the XX - beginning of the XXI century)]. Extended abstract of Candidate's thesis. Kyiv, 44 p. [in Ukrainian].

10. Smelianska, V. V. (2011). Tendentsii rozvytku rannoho navchannia inozemnykh mov u pochatkovykh shkolakh SShA [Trends in the development of early foreign language learning in US primary schools]. Nizhyn, $262 \mathrm{p}$. [in Ukrainian].

11. Smirnova, L. L. (2010). Sotsiokulturna kompetentnist u strukturi pidhotovky uchyteliv inozemnoi movy Polshchi:[ Socio-cultural competence in the structure of Polish language teacher training in Poland]. Candidate's thesis. Kirovohrad, 293 p. [in Ukrainian].

12. Tadeieva, M. I. (2011). Suchasni tendentsii rozvytku shkilnoi inshomovnoi osvity v krainakhchlenakh Rady Yevropy (porivnialnyi analiz) [ Modern trends in the development of school foreign language education in the member states of the Council of Europe (comparative analysis)]. Doctor's thesis. Luhansk, 525 p. [in Ukrainian].

13. Talalai, Yu. O. (2017). Modernizatsiia navchannia inozemnykh mov u starshykh shkolakh krain Tsentralnoi Yevropy v umovakh multylinhvizmu [Modernization of foreign language teaching in high schools of Central Europe in the context of multilingualism]. Candidate's thesis. Drohobych, 236 p. [in Ukrainian].

Стаття надійшла до редакції 22.03.2021 